\title{
Multinational Subsidiary Performance: Evidence from the Ghanaian Banking Sector
}

\author{
Michael Lawer Tetteh \\ School of Business, Zenith University College, Accra-Ghana \\ michael.tetteh@zenithuniversitycollege.org \\ and \\ Peter Carlos Okantey \\ William Ofori-Atta Institute of Integrity, Central University College, Accra-Ghana \\ DOI//http://dx.doi.org/10.4314/gjds.v13i1.3
}

\begin{abstract}
The global economic volatility has given rise to diverse firm operational strategies including internationalization through subsidiary establishment. This has aroused the interest of scholars to the study of multinational firm performance. The study seeks to ascertain the factors that contribute to the performance of multinational subsidiary banks in Ghana. Using an unbalanced random effects panel regression estimation following the Hausman specification test, the study found that increasing bank size does not necessarily lead to performance. As it stands, the Multinational Subsidiary (MNS) banks under perform as they increase in size. It was further noted that the banks are inefficient and so shift their costs and risks to customers in the form of high interest charges on credit. Notwithstanding, it appears that older MNSs perform better than the relatively younger ones. The study found that leadership origin does not have any significant impact on bank performance. Evidence was, however, found about the significant influence of the host country economic conditions on MNS performance.
\end{abstract}

Keywords: Multinational Subsidiary, Performance, Banking, Panel Data Model, Ghana

\section{Introduction}

The development and spread of globalization has resulted in the entry of more Multinational Corporations (MNCs) into several economies notably emerging ones (Singh, 2012). As a result of this growing global phenomenon, Ghana has witnessed tremendous growth in the arrival of multinational companies into the country in recent times. The interest in these emerging economies is not surprising given the recent global economic crisis that shook the financial and economic foundations of the developed economies with its aftershock 
hitting almost every economy in the world in one way or the other. Following the present heightened volatility in the global economy, more firms are looking forward to expanding their operations into relatively 'low-risk' countries in search of new opportunities to solidify their brands for high yield investments, and to diversify the risks that they are exposed to as a measure of prudent operational risk management (Hull, 2010).

As it stands, such multinational intentions can be capped as strategic since they go a long way to increase firm-shareholder value in the medium to long-term (Choi and Czechowicz, 1983). Singh (2012: 407) indicates among other things that, MNCs enter new multinational markets due to the availability of resources in the host country and the presence of relatively low priced skilled labour or workforce in the host country. This assertion is true to a very large extent given the cases of emerging countries such as India and China (Ambos and Birkinshaw, 2010). In the case of Apple for instance, it has moved its production unit to China to enjoy and take advantage of the skilled but relatively less expensive labour force to produce the same quality of products for the world market. The same situation exists for world class clothing brands establishing production plants in Bangladesh. Such initiatives also give a clear indication of superiority in terms of competitive advantage over local rivals which is crucial for market share and for that matter returns on investment (Cho, 1986; Nguyen, 2011).

The presence of MNCs in the Ghanaian banking sector is not a new phenomenon. The history of subsidiary banking in Ghana dates back to pre-independence (Ghana Banking Survey, 2011). This era saw the incorporation of Barclays Bank and Standard Chartered Bank [then Bank of British West Africa in 1896] (GSE, 2010: 88). These Multinational Subsidiaries (MNSs) have been operating in Ghana prior to the birth of indigenous banks post-independence (see the case of Ghana Commercial Bank). Until the recent 'banking revolution', there were fewer local and foreign banks operating in Ghana. Hitherto, the banking system was characterized by less competition with the few existing banks providing similar services (little or no product differentiation) and poor service quality coupled with high service charges.

Following the arrival of more foreign subsidiary banks, the sector has witnessed great transformation in terms of competition through product innovation and service quality (Venaik et al., 2005) to attract new (unbanked population) and existing customers to grow their share of the market. By inference, these MNSs believe that they have a competitive advantage over their local rivals though it is in a different geographical setting.

From the extant multinational subsidiary performance literature, there appear to be an effort to pin the performance of the foreign subsidiary to its parent company (see Ambos and Birkinshaw, 2010). Meanwhile, Nguyen (2011), posits that it is more suitable to study the performance of a foreign subsidiary as a separate unit arguing that a firms' competitive advantage in a particular market rests on its available resources and competencies in that market or firm-specific advantages. A number of studies (Venzin et al., 2008; Gao et al., 2008; Sufian, 2012), have studied the performance of MNSs. Notwithstanding, quite a number of 
these have been in developed country contexts. Though the reliability and validity of such studies are not in doubt, it is intuitive to say that economic, geographical, leadership and contextual differences can result in different outcomes and findings. In addition, the concentration of majority of the studies has been centered on a mix of firms from different sectors with the potential to result in misleading findings (Sufian, 2012 for single sector concentration).

In light of the above and following the performance (profit and branch expansion wise) of multinational banks in Ghana over the years, this current study sought to ascertain the factors that drive the performance of these multinational bank subsidiaries. The rest of the paper is organized as follows: The next segment discusses the literature on firm multinationality and performance followed by the research design and then discussion of the empirical evidence. The paper concludes with the summary and recommendations for future study.

\section{Literature Review}

\section{Theory of Comparative Advantage}

A number of theories have emerged regarding why businesses decide to go international. Some of the commonly held views include the theory of comparative advantage; the imperfect markets theory and the product cycle theory (Madura, 2008). The comparative advantage theory has largely been talked about in the international businesses arena particularly in relation to production of goods and services as it is seen as a key strategy for efficiency. The application of internationalization theory to the multinational firm performance is not a new phenomenon. It has widely been tested empirically and confirmed to provide a good measure of multinational firm performance assessment in the international environment (Gerke \& Benson-Rea, 2012). Matysiak and Bausch (2012) make us understand that multinational firm performance could be at three levels. These are industry level, country level and firm level performance indicators. Though all three components of Matysiak and Bausch (2012)'s submissions are relevant, this current study focuses mainly on the country and firm level performance indicators only.

Though the quest for firms to go multinational is on the rise (Ambos \& Birkinshaw, 2010) due to some of the reasons mentioned in our earlier discussion, Morgan et al. (2003) are of the view that the advancement of competitive advantage in one key area or another does not necessarily ensure sustainability over time. This suggests that firm longevity in the international market or host country goes beyond just share value maximization pursuance, but could reach the doorstep of strategic leadership and effective management. Others (such as Fang et al., 2007) have also expressed the view that for a multinational firm to be in a competitive advantage position over time, it must possess valued and rare resources such as knowledge. Knowledge here could extend from technical to human resources advantages. 
One key observation in the multinational enterprise business context specifically in the Ghanaian banking sector is the 'relative ease' with which the banks have been able to settle and flourish in the competitive and growing market. One reason that the study can assign to the phenomenon is the hitherto lack of competition in the banking system prior to this era of "banking revolution" in Ghana. It could also be argued (D'Aveni, 1994) that one of the reasons to such incidence could be the 'hypercompetitive' environment in which these firms are operating. But can the same be said of the Ghanaian multinational case? While it is true and evident that the banking system is highly saturated as at present, technological, superior customer service and real product differentiation strategies are set to place the leaders in these strategies ahead of their peers. Notwithstanding, reactive tactics are often taken by competitor firms to new strategies by their counterparts (Morgan et al., 2003). One other reason that is often assigned to multinational performance in local markets is their knowledge and experience of the global market. As noted by Fang et al. (2007), though knowledge and experience is not easily transferable, a successful transfer offers resistance to imitation and substitution advantages thereby placing the multinational firm in a unique position in the industry to compete well.

\section{Imperfect Market Theory}

One other theory that comes to play in the multinational business realm is the imperfect markets theory. In the real world international business front and in the real world situation, perfection in terms of market conditions (factors of production) is almost nonexistent. By a perfect market, Madura (2008) explains that in the situation where factors of production are easily transferable (see Fang et al., 2007 on the difficulty in resource transferability), then such factors would move to where they are most needed. As it stands, the real world is "imperfect" such that some factors of production are either immobile or become very expensive and economically unviable to move them to where they are needed. Hence, imperfect markets serve as a form of incentive for firms to go international (Madura, 2008: 6). This suggests that multinational banks venture into foreign markets to take advantage of the resources (though they also bring along a lot of resources) and market potentials in the host country and also to take advantage of local bank lapses where they envisage to outperform or at least be at par with their local counterparts.

Sturm and Williams (2009) indicate that in a developing country context such as Ghana, foreign or subsidiary banks appear to perform better than their local counterparts. While this point is contestable, it is important to understand that firms have specific advantages (FSAs) such that foreign banks are likely to have greater advantage over local counterparts in areas such as technology and innovation and also draw on the supervision, attention and coaching from their global parent companies (Ambos and Birkinshaw, 2010; Venaik et al., 2005). Sturm and Williams (2009)'s point could also be challenged on the grounds that local counterparts in developing countries might have gained 'deep-rooted' grounds in the market which is likely to make it very difficult if not impossible for foreign subsidiary counterparts to break. While such arguments are healthy, the focus of this paper is solely on 
multinational bank performance and not a comparative performance study between local and foreign counterparts.

\section{Product Cycle Theory (PCT): International Product Life Cycle}

According to the PCT, firms perform well in their home countries basically because they possess some key advantages over existing competitors in the market (Madura, 2008). The intuition is that, because the issue of information asymmetry is less in the home country, it is prudent for firms with multinational intention to solidify their gains at home before they venture into the international marketplace. Venturing into the international market could be as a result of foreign demand for quality services (that means that such services already exist in the "to-be" host country) or a complete need of a service or product. Prior to the 'invasion' of multinational banks into Ghana, the need for product differential in the banking sector was less important, if not almost nonexistent. However, due to the recent intense competition in the sector as a result of the presence of multinational and new local banks, the sector has witnessed tremendous change in the bid to gain market share. The framework in Figure 1 (Madura, 2008) gives a pictorial perspective of the PCT theory of firm multinational intention.

Figure 1: PCT theory of firm multinational intention

$\mathbf{4}$ b. Firm's foreign business
declines as its competitive
advantages are eliminated.

4 a. Firm differentiates product/ service from competitors and/or expand product line in foreign country.

\section{Firm exports service to accommodate foreign demand}

1. Firm creates product/service to accommodate local demand
3. Firm establishes foreign subsidiary to establish presence in foreign country and possibly to reduce losses.

Source: Madura (2008) 


\section{Firm Specific Advantages (FSAs) and Multinational Firm Performance}

Multinational firms expand to other environments in the form of subsidiaries mainly for strategic reasons. While this observation is key, it is also worth noting that the advantages that multinational firms enjoy in foreign jurisdictions are to a very large extent tied to their inherent specific characteristics. Fang et al. (2007) outline some of these as available resources, capabilities, and competencies. It is even asserted in certain quarters (Sturm and Williams, 2009) that banks from foreign countries are able to venture into new territories and overcome host country challenges due to some unknown and unmentioned reasons. One key reason, though that is basic for multinational expansion, is to maximize shareholder wealth (Madura, 2008). Likewise, Dunning (1993) noted that one of the fundamental reasons why firms set up or develop new markets in other environments is because it goes a long way to positively influence their profitability and performance.

According to Delios and Beamish (2002), MNCs venture into international markets due to the availability of intangible assets (such as knowledge/skills base of employees) in the host country. In a related proposition, Ando (2011) contend that the staffing policies and human resource competencies of MNCs play a key role in the competiveness of their subsidiary companies in unfamiliar markets. The author sees this staffing mix in multinational subsidiaries (MNSs) as one of the most critical strategic decisions for MNCs to enjoy competitive advantage over the host country counterparts (Ando, 2011: 131). While these assertions are core to firm value maximization, Nguyen (2011) asserts that firm specific advantages (FSAs) are some of the key drivers of multinational subsidiary performance which stems from the unique resources and capabilities of the subsidiary firm.

These advantages are sometimes referred to in certain quarters (Morgan et al., 2003; Fang et al., 2007; Ambos and Birkinshaw, 2010) as firm-specific resource based perspectives to multinational establishment and performance. According to Morgan et al. (2003), it is in this light of achieving competitive advantage that firms utilize their available resources to strategically position themselves in the specific product market in which they find themselves. From the hypercompetitive view, however, Fang et al. (2007: 60) believe that firms gain competitive advantage in foreign markets as a result of cost/quality, timing/ knowhow, strongholds, and 'deep pockets.' It is interesting to note that these FSAs outlined by Fang et al. are all evident in the Ghanaian case where multinational bank subsidiaries try to beat cost of service provision while offering superior service; have strategic entry methods and possess high technological knowhow as a result of their parent company strings; and more evidently, their strong financial muscle due to the high initial capital requirements as well as huge infrastructural development cost. Nonetheless, these banks are able to brace the storm to establish in a foreign land. 


\section{The Role of Leadership in Multinational Business Performance}

The role of leadership in Multinational Corporations' (MNCs) success in Ghana cannot be underestimated. Leadership in every aspect of an organization is deemed of great importance. According to Northouse (2007), leadership is said to be a process that involves influencing others, occurs within a group context, and involves goal attainment. It is a process whereby one individual influences other group members toward the attainment of defined group or organizational goals (Yukl, 1998). Leadership can also be perceived as a combination of self-mastery and social intelligence (Goleman, 2008).

Alternatively, leadership can be defined as the accomplishment of a goal through the direction of human assistants. Thus, a successful leader is one who can understand people's motivations and enlist employee participation in a way that marries individual needs and interests to the group's purpose (Prentice, 1961). It is considered possessing the ability to increase followers' sense of self-efficacy by increasing self-worth and communicating confidence and high expectations by linking followers' goals to mission, which serves as a basis for identification and the generation of loyalty by connecting behaviours and goals to a dream of a better future (Shamir, 1995).

Hence, leadership is a set of traits, qualities and behaviours possessed by the leader that encourages the participation, development, and commitment of others within the organization. Leaders therefore build partnerships, 'walk the talk', and shows incredible drive and enthusiasm to get things done (Bolden \& Gosling, 2006). Leadership is about producing results and getting the most out of people. The MNC leader must therefore take cognisance of the fact that people (the local people) are the most relevant stakeholders in his/her quest to be successful.

For great performance in a multinational setting, the leadership of the organization must seek to understand the diversity, beliefs and cultures of the society in order to make a positive impact through performance. MNC Leaders must therefore appreciate the fact that when working across cultural borders, there is the need for a shared understanding of purpose, goals, priorities, and methods which are usually influenced by local conditions (Magale \& Sutherland, 2010).

Figure 2 is a proposed model MNCs operating in Ghana and other multicultural environments can adopt for use by their leaders. The model is a 'seven-step'process global leaders (leaders of multinational corporations) can adopt as they penetrate new markets. The steps of the model are: creating a common purpose and establishing a team; developing an environment of trust among team members; encouraging participation, collaboration and integration; and communicating effectively. 
Figure 2: Multinational Leadership Model

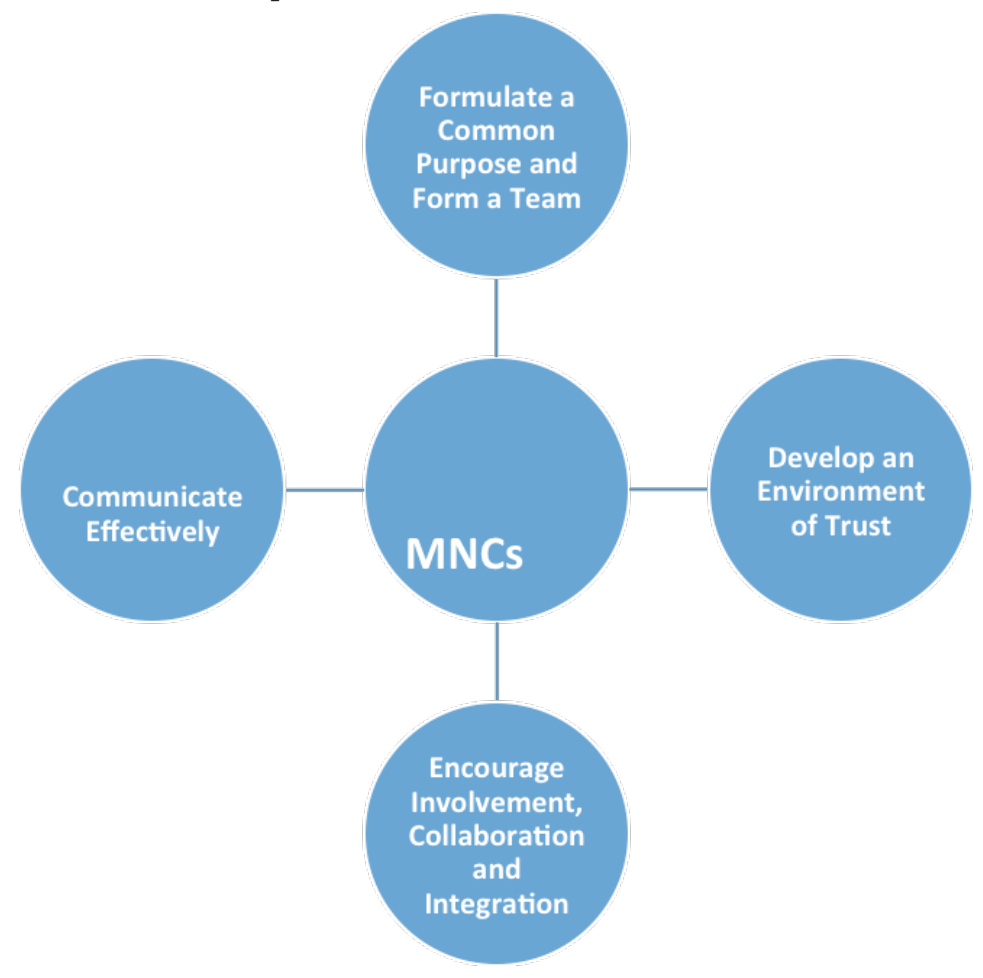

Source: Author's Construct 2014

\section{Methodology}

\section{The Regression Model}

Similar to Sufian (2012), the paper utilizes the panel regression approach to ascertain the performance of the multinational banks. The regression model is specified in equation 1. Performance was assessed using the return on assets (ROA) ratio of the subsidiary banks. There are other numerous accounting-based firm performance measurement indicators aside ROA such as: return on equity (ROE) and Tobin's $\mathrm{Q}$. The most widely used ones are ROA and ROE. Though these performance measures give distinct and very important indications of management effectiveness and corporate performance in banking, the study selected the ROA as our measure of performance mainly because our focus is on how the MNCs performed (operational profitability) per their investments in available resources and not how they generate worth for investors. More importantly, return on assets is very useful when potential dangers associated with financial strategies meant to purport good performance are to be avoided (Hagel et al., 2010). 
Subsequently, performance of the subsidiary banks was specified on some FSA variables (sales, firm size, efficiency and age), host-country economic condition (GDP) and other control variables (credit risk, entry strategy and leadership origin). The variables included in the model (see table 1) were drawn from the multinational subsidiary extant literature (Dunning, 1993; Nguyen, 2011; Morgan et al. 2003; Sufian, 2012; Fang et al., 2007). The paper includes leadership origin and host country economic condition (GDP) to the performance model since they have received little attention in the multinational firm performance domain. The panel regression model is specified as:

$$
F P E R F_{i t}=\beta_{0}+\beta_{i t} X_{i t}+\lambda_{t}+\varepsilon_{i t}
$$

where;

$F P E R F_{i t}$ denotes performance of firm $i$ at time $t ; \beta_{0}$ is the intercept; $\beta_{i t} X_{i t}$ is a vector matrix of coefficients $\left(\beta_{i t}\right)$ and respective independent variables $\left(X_{i t}\right)$ for firm $i$ at time $t$ stated in the forms:

$$
\beta_{i t}=\left[\begin{array}{c}
\beta_{1} \\
\beta_{2} \\
\beta_{3} \\
\beta_{4} \\
\beta_{5} \\
\beta_{6} \\
\beta_{7}
\end{array}\right] \quad X_{i t}=\left[\begin{array}{c}
\text { Firm Size } \\
\text { Credit Risk } \\
\text { Age } \\
\text { Efficiency } \\
\text { Entry Strategy } \\
\text { Leadership Origin } \\
\text { Host Economic Condition }
\end{array}\right]
$$

$\lambda_{i}$ is the unobservable individual time effects; $\varepsilon_{i t}$ and is the error term.

In panel regression analysis, it is ideal to find out whether the variations among the individual group effects are fixed or random. This is appropriate to aid in the kind of panel regression analysis to estimate. In order to arrive at this conclusion, the Hausman's (1978) specification test is often employed (for example Greene, 2008). The test compares an estimator $\hat{\theta}_{1}$ that is known to be consistent with an estimator $\hat{\theta}_{2}$ that is efficient under the assumption being tested. The null hypothesis is that the estimator $\hat{\theta}_{2}$ is indeed an efficient (and consistent) estimator of the true parameters. The estimator follows a chi-square distribution. If the null hypothesis is rejected. Thus the random effects model is rejected in favor of the fixed effects model. 


\section{Measurement of Variables}

\section{Size}

The size of a firm plays a significant role in bank performance (Tetteh, 2014) as it could lead to the enjoyment of economies of scale. Nguyen (2011) is of the view that firms could even use their size to their advantage. One such advantage is economies of scale. Tetteh (2014) however showed that in Ghana, firms tend to perform poorly as they grow in size. Notwithstanding, Becker et al. (1998) suggests that it is worth including firm size since it more or less acts as an instrumental variable capable of catering for other related variables. It is also asserted (Goddard et al., 2004) that bigger size firms are able to access capital at lower cost thereby lowering their total expenditure. In this study, size is measured as the logarithm of total assets. Following the preceding arguments, a negative relationship between size and bank performance is expected.

\section{Credit Risk}

Banks face a lot of risks especially credit risk as a result of the fundamental role they play in the financial intermediation process (Alhassan et al., 2015). One of the key fundamental roles is making funds available to creditworthy deficit units. It is this same functionality that generates substantial earnings for banks (Tetteh, 2014). This becomes a great challenge when the supposed creditworthy client tends out to be a true unworthy borrower. The problem is even compounded when the loan is delinquent. In this case, doubtful debts and the subsequent necessity for provision for such cases go a long way to adversely affect the profitability of banks (Trujillo-Ponce, 2013) suggesting an inverse relation between credit risk and performance. Thus lower doubtful debts to total loan portfolio (lower credit risk) leads to better profitability. On the contrary, Alhassan et al. (2015) found a significant positive relationship between credit risk and performance. It is therefore expected that credit risk will have a positive impact on bank performance. Credit risk in this current study is measured as the amount of doubtful debts to total loan portfolio.

\section{Age}

Older firms in a particular sector are thought to have enough operating experience to enable them gain competitive advantage over younger entrants into the same market. Similar to what others have done (see Delios and Beamish, 2002), age was measured as the date of incorporation of the subsidiary firm in Ghana. Similar to other studies (Hennart et al., 1998) Delios and Beamish (2002) showed that the age of subsidiary firm has a significant positive relationship with profitability. Following the existing literature, it is expected that there will be a significant positive relationship between subsidiary bank age and performance. 


\section{Operational Efficiency}

Banks incur several costs in their operations. Notwithstanding, these costs are necessary for revenues to be generated. In this light, it is prudent for banks to make judicious use of their inputs to generate substantial outputs. By this, banks must operate efficiently by significantly reducing their operational costs in order to remain competitive and generate profit (Sturm and Williams, 2009). Jara-Bertin et al. (2014) indicates that high bank efficiency leads to better performance. In this paper, bank efficiency is measured as the cost of operation to operating income (see Tetteh, 2014; Burger and Moormann, 2008 for instance). Lower cost to income is therefore expected to have a positive significant impact on bank performance.

\section{Entry Strategy}

When firms intend to enter new markets, they are faced with several entry mode strategies (Li et al., 2011). These could range from joint venture to wholly owned subsidiary set-up. It is thought that when multinational firms want to enter a new market, they could solidify their grounds by either applying the bottom-up approach of gaining experience with time (wholly owned approach) or capitalize on the experience of existing similar firms through partnership (possibly a merger). Delios and Beamish (2002) in their study found that entry mode strategy plays a key intermediary role for multinational subsidiary performance. Specifically, the authors showed that when firms use the wholly owned entry strategy, it does not necessarily influence profitability. Notwithstanding, it was shown that entry mode is a vital multinational subsidiary strategy that positively affects subsidiary survival and profitability. We expect wholly owned subsidiaries to perform better than their counterparts. There is however no consensus in the literature on whether wholly owned subsidiary produces better performance than mergers or partnership.

\section{Leadership Origin}

Leadership involves goal attainment as well as self-mastery and social intelligence (Goleman, 2008). In addition, it requires working with people to produce good results. In order to succeed and perform in a multinational setting, the leadership of the organization must seek to understand the diversity beliefs and cultures of the society in order to make a positive impact through performance (Mogale \& Sutherland, 2010). Expatriate managers or managers from the subsidiary country are likely to bring their international ideas to the new market which may drive change more especially if the ideas pose significant threat to local and existing firms in the same industry. Notwithstanding, managers from the host country could also bring a lot of ideas as leaders more especially since they stand a greater chance of knowing the market than the leader from the subsidiary's country of origin. In this era of information sharing, it is possible also that the leader coming from the subsidiary's country of origin might have more authentic and strategic information than the local leader. 
However, the paper expects that foreign bank leaders in Ghana would lead their banks to perform better their Ghanaian counterparts.

\section{Host Country Economic Condition}

Banks in general are exposed to the macroeconomic conditions of the country they operate in. Most often, the effect is seen to be positive (Jara-Bertin et al. (2014). In their study, Demirguc-Kunt and Huizinga (2000) employed the annual growth rate of gross domestic product (GDP) and gross national product per capita as a proxy for economic growth. They found that good economic condition positively impacts on the performance of banks operating within that economy. Aside this, de la Torre et al. (2011) has shown that GDP growth is one of the key ingredients of bank credit facilitation. Similar results shown by (Demirguc-Kunt and Huizinga, 200o; de la Torre et al., 2011; Jara-Bertin et al., 2014) are expected in this study as well. Thus all things being equal, the paper anticipates that favourable economic conditions in Ghana would positively impact on multinational bank performance in the country. Host country economic was measured as GDP of Ghana at constant prices.

Table 1: Model variables and measurement

\begin{tabular}{|l|l|l|}
\hline Variable & Measurement & A priori Expectations \\
\hline Performance & Return on assets (ROA) & N/A \\
\hline Firm size & Logarithm of total assets & + \\
\hline Credit risk & Bad debt or doubtful debt to total loans & - \\
\hline Age & Year of incorporation in Ghana & + \\
\hline Operational Efficiency & Overhead cost to operating income & + \\
\hline Entry strategy & Greenfield Investment =1; Acquisition = o & + \\
\hline Leadership origin & Ghana =1, Others = o & + \\
\hline $\begin{array}{l}\text { Host country economic } \\
\text { condition }\end{array}$ & GDP at constant prices & + \\
\hline
\end{tabular}

\section{Data and Sample Size}

The study sampled fourteen (14) multinational banks in Ghana over a ten year period (2003 to 2012). This resulted in an unbalanced panel of 109 observations in total. However, due to the unbalanced nature of the data, the total observation or sample dropped to 108 at the empirical estimation stage. By sampling all the multinational subsidiary banks in the country over a ten year period (2003-2012), the paper can assert that our population has been adequately covered thus giving the study a wide scope (data-wise) and hence its generalizability and reliability in the growing multinational bank subsidiary performance literature is not in doubt. Financial data for the regression were extracted from the 
published financial statements and annual reports of the respective banks over the study period. The economic data (GDP) of Ghana over the period was, however, sourced from the World Economic Outlook (WEO) Database, April 2014. The entry strategy as well as the leadership information of all the banks was obtained from the respective banks' profiles and documentations which are publicly available.

\section{Empirical Results}

\section{Descriptive Statistics}

Descriptive statistics of the research data is presented in Table 2. From the table, it can be observed that at least one of the banks recorded a loss over the study period as evidenced by the negative ROA of - 0.0348. In terms of size, the average size (log transformation) of the multinational banks is 17.64 with the lowest being 11.475. It appears also that on average, the banks have doubtful debts of (0.300). Thus one-third of their loan portfolio size is made of doubtful debts vis-à-vis their total loans. This can be seen as rather quite alarming per the maximum ratio of (18.1474).

The average age of the banks is 31.2 years (31 years, 2 months). The oldest bank is 116 years and this happens to be Standard Chartered Bank. It therefore means that the bank has been in operation in the Gold Coast era before independence. Our efficiency summary result indicates that on a whole, the banks have not managed their own operational costs very well in relation to their income (2.73). Results from the table paint picture of the fact that majority of the multinational banks (80.7\%) entered the Ghanaian banking market by establishing an entirely new subsidiary (Greenfield Investment) and only a few choose to enter the sector by using mergers and acquisitions ( $M$ \& A) strategy and the leadership has mostly been held by expatriates (0.2936).

On the macroeconomic side, the average GDP (indicator of the economic condition) of Ghana over the study period is 22.36 billion. There was, however, a dip (Gh 15.786 billion) along the way and a peak of Gh $\$ 30.099$ billion over the same study period (2003-2012). The interrelationships between all the variables discussed thus far are presented in Table 3. 
Table 2: Summary of data

\begin{tabular}{|l|l|l|l|l|l|}
\hline Variable & Obs & Mean & Std. Dev. & Min & Max \\
\hline ROA & 109 & 1.055636 & 7.186325 & -0.0348 & 58.06277 \\
\hline SIZE & 109 & 17.64881 & 2.666145 & 11.47463 & 21.59484 \\
\hline RISK & 109 & 0.30044 & 1.859717 & 0.000257 & 18.14738 \\
\hline AGE & 109 & 31.23853 & 36.68532 & 4 & 116 \\
\hline EFF & 109 & 2.734469 & 9.670112 & 0.000336 & 76.75144 \\
\hline ENTRY & 109 & 0.807339 & 0.3962104 & 0 & 1 \\
\hline LEAD & 109 & 0.293578 & 0.4575043 & 0 & 1 \\
\hline GDP & 109 & 22.3632 & 4.449933 & 15.786 & 30.099 \\
\hline
\end{tabular}

\section{Correlation Analysis}

Correlation analysis is one way of determining the strength of independent variables with the dependent variable prior to estimation. It is also a quick and good way of assessing the possibility of multicollinearity between research variables prior to estimation of any regression model. Results of the Pearson correlation is depicted in the matrix presented in Table 3. From the table, it can be observed that all the independent variables have a positive association with ROA except Size, EFF and LEAD. It means that as the banks grow in size, their earnings are negatively affected probably because they lose oversight of responsibilities. This translates into inefficiency as shown by the negative relationship of EFF on ROA. A cursory look at the various interrelations among the independent variables in the matrix shows no sign of multicollineanity because the correlations between the independent variables are very low. The highest correlation coefficient is 0.3943 . There is however great argument in literature as to the acceptable correlation coefficient to determine the existence of multicollinearity among a set of explanatory variables. The paper therefore relied on a statistical test called the Variance inflation factor (VIF) test. The VIF quantifies how much the variance of the regression is inflated by individual explanatory variables. Hair et al. (2006) recommends a maximum variance inflation factor threshold of 10 . The VIF test conducted on all the independent variables recorded VIF values lower than the maximum value of 10 suggested by Hair et al. (2006) indicating absence of multicollinearity among the predictor variables. Multicollinearity is a situation whereby within a group of explanatory variables, one or more linear relationships exist or the variables are highly correlated (Koutsoyiannis, 2001). The effects of the above revelations and their empirical implications are shown in the estimation results. 
Table 3: Pearson correlation matrix

\begin{tabular}{|l|l|l|l|l|l|l|l|l|}
\hline & ROA & SIZE1 & RISK & AGE & EFF & ENTRY & LEAD & GDP \\
\hline ROA & 1 & & & & & & & \\
\hline SIZE & -0.1462 & 1 & & & & & & \\
\hline & $(0.1292)$ & & & & & & & \\
\hline RISK & $0.9490^{*}$ & -0.1478 & 1 & & & & & \\
\hline & $(0.0000)$ & $(0.1251)$ & & & & & & \\
\hline AGE & 0.0311 & $0.3943^{*}$ & 0.0252 & 1 & & & & \\
\hline & $(0.7479)$ & $(0.0000)$ & $(0.7949)$ & & & & & \\
\hline EFF & -0.0323 & -0.1291 & -0.0337 & 0.0278 & 1 & & & \\
\hline & $(0.7387)$ & $(0.1808)$ & $(0.7283)$ & $(0.7741)$ & & & & \\
\hline ENTRY & 0.0682 & -0.0101 & 0.0552 & $0.2663^{*}$ & 0.0595 & 1 & & \\
\hline & $(0.4808)$ & $(0.9168)$ & $(0.5686)$ & $(0.0051)$ & $(0.5391)$ & & & \\
\hline LEAD & -0.0881 & 0.0618 & -0.0841 & -0.0412 & -0.1025 & -0.0426 & 1 & \\
\hline & $(0.3625)$ & $(0.5232)$ & $(0.3846)$ & $(0.6708)$ & $(0.2887)$ & $(0.6597)$ & & \\
\hline GDP & $0.2074^{*}$ & $0.3494^{*}$ & 0.1857 & $-0.2157^{*}$ & -0.1553 & 0.0374 & 0.0369 & \\
\hline & $(0.0305)$ & $(0.0002)$ & $(0.0533)$ & $(0.0243)$ & $(0.1068)$ & $(0.6998)$ & $(0.7030)$ & 1 \\
\hline
\end{tabular}

Notes: Values in parenthesis are $p$-values. ${ }^{*}$ indicates significance of at least $5 \%$ level.

\section{Random Effects Estimation}

\section{Bank Size and GDP}

For our discussion, model 2 as shown in our estimation results in Table 4 is preferable. The outcome of the study shows that bank size has a negatively significant effect on profitability at the $5 \%$ level. One possible reason for this outcome could be that as the banks firms grow in size, their oversight responsibilities also increase and as such, are unable to effectively monitor and evaluate their assets. This could lead to leakages in operational modalities of the bank which have the high tendency to result in high operational costs and losses. The empirical evidence in this paper also point to the fact that increasing bank size does not necessarily increase bank profits. We can hence say that the success of any size increase will largely depend on the asset quality of the respective banks. It is important to mention at this stage that GDP plays a crucial part in this phenomenon. A careful look at the table shows that it is under model 2 (i. e. when GDP was included in the model) that the size variable became significant at the $5 \%$ level. 
One indication and interesting revelation from the above is that, since the huge portion of bank assets in Ghana are made up of loans, in the event of poor economic performance, borrowers are equally affected and by replication will have a negative effect on credit performance and consequently affect bank profitability.

Table 4: Random effects estimation results

\begin{tabular}{|c|c|c|c|c|}
\hline & \multicolumn{2}{|l|}{ Model 1} & \multicolumn{2}{|l|}{ Model 2} \\
\hline & Coef. & Std. Err. & Coef. & Std. Err \\
\hline SIZE & -0.0669 & 0.04686 & $-0.1471^{* *}$ & 0.05670 \\
\hline RISK & $0.44532^{* * *}$ & 0.06564 & $0.39045^{* * *}$ & 0.06810 \\
\hline EFF & $-0.1374^{*}$ & 0.07580 & -0.0993 & 0.07576 \\
\hline ENTRY & $0.61224^{*}$ & 0.32036 & 0.51291 & 0.31580 \\
\hline LEAD & -0.3527 & 0.27126 & -0.3364 & 0.26518 \\
\hline AGE & $0.25979^{* *}$ & 0.12283 & $0.36857^{* *}$ & 0.12831 \\
\hline CONS & $-3.1879^{* * *}$ & 0.90984 & $-3.9199^{* * *}$ & 0.94005 \\
\hline GDP & & & $0.08679^{* *}$ & 0.03618 \\
\hline R2 & 0.4197 & & 0.4513 & \\
\hline Hausman $\chi^{2}$ & 3.73 & & 7.92 & \\
\hline Prob $>\chi^{2}$ & 0.4444 & & 0.1609 & \\
\hline Obs & 108 & & 108 & \\
\hline
\end{tabular}

Notes: Dependent variable is ROA; EFF stands for Efficiency; Lead is the Leadership of the bank; GDP is the Gross Domestic Product of Ghana at constant prices and Cons is the constant; ${ }^{* * *}$ denotes significance at 1\%; "denotes significance at $5 \%$ and ${ }^{*}$ denotes significance at $10 \%$.

\section{Credit Risk}

Prudent risk management practice is one of the key focus areas of bank operation. The study looks at the effects of credit risk on the profitability and hence performance of multinational banks in Ghana. Results from Table 4 reveal that the credit risk variable (Risk) has a significantly positive relationship with ROA at the $5 \%$ level. The paper finds this outcome very interesting following the many assertions in the literature of the negative repercussion of credit risk on bank profitability. One possible reason for this outcome is the high interest rate charged by the MNC banks and banks in general in Ghana on loans and overdrafts. Our result is consistent with the findings of Alhassan et al. (2015). In essence, banks appear to transfer the cost of non-performing loans onto good borrowers in the form of high interest charges. This, we can say, has accounted for the current outcome in this study. The positive outlook in this case is what we can refer to as the collusion conundrum of the banks against customers. The reasoning behind this is that, while bank customers, regulatory agencies and 
allied institutions complain about the 'super normal' profits posted by banks on year-onyear basis due to the high interest spreads, none of the banks seems to be bothered as the phenomenon appears to be an industry practice and it is more like a 'financial cartel'. It will take stronger competition in the market coupled with alternative and innovative revenue generation sources for the banks to break away from such practices. It is therefore not surprising to trace a huge portion of the operating income of the banks to interest income. The judiciousness or otherwise of how such incomes are utilized in the operation of the banks is discussed next.

\section{Operational Efficiency}

The resourcefulness of any firm could be assessed through their operational costs vis-à-vis their operational income. To this effect, when a bank has an overlapping cost against its income, then that firm can simply be described as inefficient. Our empirical results reveal that the banks have been inefficient over the study period. This is evident by the negative impact of the efficiency variable (EFF) on ROA. From the table (Table 4), we can observe that EFF is insignificant. The insignificance of EFF signifies that despite the operational inefficiency as a result high operational costs in the system, this does not significantly influence the performance of these banks.

\section{Host Country Economic Conditions}

Economic conditions can affect the performance of banks. This is because banks in general are exposed to the macroeconomic conditions of the country they operate in. Our results indicate that host economic condition as measured by GDP positively impacts on MNS bank performance. This current finding corroborates the view of (Jara-Bertin et al. 2014). By implication, the well-being of the Ghanaian economy would go a long way to promote good business environment and better bank performance in the economy.

\section{MNC Entry Strategy and Leadership Origin}

It is an undeniable fact that MNCs only expand to new markets when they spot an investment opportunity in that new market. One of the key initial decisions of MNCs is the entry strategy as this could go a long way to affect their bottom-line (either positively or negatively). Results from our study show that a vast majority of the MNC banks entered the Ghanaian market through the 'greenfield' approach (establishing from the scratch). Only a few of them either merged or acquired other existing banks in the sector. It can also be observed that the entry strategy of these banks has a positive significant influence on their performance at the $10 \%$ level. By implication, the banks have been very strategic on their respective entry strategies. The fact, however, remains to be established as to which entry strategy is the best for the Ghanaian market. With the same positive relationship, no significant relationship between the two variables under model 2 was found. An insignificant negative relationship was also found between bank performance and 
leadership origin. In addition, the result of the paper shows that the age of the banks have a positive significant impact on their performance at the $5 \%$ level. This means that the older banks are able to rely on their experiences in the market to outweigh competition and make more profit than their younger counterparts.

The study found a positive significant impact of GDP on bank performance. This means that good macroeconomic conditions aid in increasing the profitability of the banks. Thus in good times, general economic conditions will be favourable to the public and businesses in general who are the ultimate customers of these banks. In short, the Ghanaian macroeconomic cycle has direct effect on MNC banks operating in Ghana. The $\mathrm{R}^{2}$ values $(41.97 \%$ and $45.13 \%$, respectively) for model 1 and model 2 show high association between ROA and its determinants. Following the Hausman test, the random effects estimation was deemed appropriate for the study as shown in Table 4.

\section{Summary and Conclusion}

MNS banks continue to play significant roles in the Ghanaian economy. Aside serving as agents of change, they have contributed greatly in creating employment, functioned as sources of Foreign Direct Investment (FDI) flow into the country (Abdulai, 2005) and have contributed to deepening the financial sector. The study investigated the factors that drive the performance of MNC banks operating in Ghana over a ten-year period. Findings of the paper show that the success of the MNSs can be attributed to high interest income (interest charges on loans and advances) through high credit pricing practices. This was evident by the positive significant impact of the credit risk variable on ROA. Such practices clearly show lack of creativity in terms of revenue generation streams and hence the evidence of inefficiencies in the banking system.

In particular, the paper found that the performance of the banks is negatively affected by their inefficiencies as a result of high operational costs vis-a-vis operating incomes. It was also evident that the banks are inefficient at using their generated revenue as operational costs far outweigh their operating incomes. This is surprising following the assertion that home managers would have all the leadership know-how to lead a multinational in their home country. Notwithstanding, since leadership transcends borders, a well-trained crosscultural leader can be very effective in a foreign country with the support of local peers. Evidence was also found about the contribution of experience of the MNS bank in the host country to profitability. It was observed that macroeconomic performance (GDP) of Ghana has a positive significant influence on MNS bank profitability.

The arrival of more MNSs into the country has heightened competition for market share and profitability. This has resulted in high operational costs (brand building, infrastructure expansion) by the banks in order to remain competitive. While it is strategic to be competitive, it would be worthwhile and prudent for MNS banks to manage their operational costs vis-à-vis their incomes in order to be cost efficient. Such actions would not only affect 
the general health of the bank, but would as well lead to lower costs of funds to borrowers and hence reduce credit risk exposure. In this light, MNS banks must make use of efficient operational strategies in order to maximize resource usage.

\section{References}

Abdulai, I. (2005). Sectoral analysis of foreign direct investment in Ghana. Bank of Ghana Working Paper Series. WP/BOG-2005/15.

Alhassan, A. L., Tetteh, M. L. and Brobbey, F. O. (2015). Market Power, Efficiency and Bank Profitability: Evidence from Ghana. Economic Change and Restructuring, 49 (1), pp. 71-93.

Ambos, T. C. and Birkinshaw, J. (2010). How Do MNC Headquarters Add Value? Management International Review, 50 (4), pp. 449-469.

Ando, N. (2011). Isomorphism and foreign subsidiary staff policies. Cross Cultural Management: An International Journal, 18 (2), pp. 131-143.

Becker, C. L., De-Fond, M. L., Jiambalvo, J. and Subramanyam, K. R. (1998). The Effect of Audit Quality on Earning Management. Contemporary Accounting Research, 15, pp. 1-24.

Bolden, R., and Gosling, J. (2006). Leadership Competencies: Time to Change the Tune? Leadership, 2, pp. 147-163.

Burger, A. and Moormann, J. (2008). Productivity in banks: myths and truths of the Cost Income Ratio, Banks and Bank Systems, 3 (4), pp. 85-94.

Cho, K. R. (1986). Determinants of Multinational Banks. Management International Review, 26 (1), pp. 10-23.

Choi, F. D. S and Czechowicz, I. J. (1983). Assessing Foreign Subsidiary Performance: A Multinational Comparison. Management International Review, 23 (4), pp. 14-25.

D'Aveni, R. (1994). Hypercompetition: Managing the Dynamics of Strategic Maneuvering. New York: The Free Press.

Delios, A. and Beamish, P. W. W. (2002). Survival and Profitability: The Roles of Experience and Intangible Assets in Foreign Subsidiary Performance. Available at: http://ssrn. com/abstract=305345. Accessed: $3^{\text {rd }}$ December 2014.

de la Torre, A. , Feyen, E. and Ize, A. (2011a). Financial development: structure and dynamics. Policy Research Working Paper Series, No. 5854. Washington, DC: The World Bank.

Demirguc-Kunt, A. and Huizinga, H. (2000). Financial structure and bank profitability. Policy Research Working Paper Series, No. 2430. Washington, DC: The World Bank. 
Dunning, J. H. (1993). Multinational enterprises and the global economy. Don Mills, Ontario: Addison-Wesley Publishing Company.

Fang, Y., Wade, M., Delios, A and Beamish, P .W. (2007). International Diversification, Subsidiary Performance and the Mobility of Knowledge Resources. Strategic Management Journal, 28 (10), pp. 1053-1064.

Gao, G. Y., Pan, Y., Lu, J. and Tao, Z. (2008). Performance of Multinational Firms' Subsidiaries: Influences of Cumulative Experience. Management International Review, 48 (6), pp. 749-767.

Gerke, A. and Benson-Rea, M. (2012). Growing new MNEs in New Zealand: the FSA/CSA framework revisited. Multinational Business Review, 20 (2), pp. 153-177.

Ghana Banking Survey (2011). Sustaining Growth: Challenges and Opportunities. Available at: www.pwc.com/gh. Accessed: $3^{\text {rd }}$ January 2014.

Ghana Stock Exchange (2010). Fact Book (2010). Accra, Ghana: Ghana Stock Exchange Publication.

Goddard, J., Molyneux, P. and Wilson, J.o.s. (2004). The profitability of European banks: a cross-sectional and dynamic panel analysis. Manchester School, 72(3), pp. 363-381.

Goleman, D. (2008, February 28). Archive for the 'Leadership' Category. Available at: http:// www.danielgoleman.info/category/leadership/. Assessed: $23^{\text {rd } J a n u a r y ~} 2010$.

Greene, W. H. (2008). Econometric Analysis. (6 ${ }^{\text {th }}$ ed.). Upper Saddle River, NJ: Prentice Hall.

Hausman, J. A. (1978). Specification tests in econometrics. Econometrica, 46, pp. 1251-1271.

Hagel, J., Brown, J. S. and Davison, L. (2010). The Best Way to Measure Company Performance. Harvard Business Review. Available at: https:/hbr.org/2010/o3/the-best-way-tomeasure-compan.html. Accessed: $20^{\text {th }}$ October 2015.

Hair, J. F., Black, W. C., Babin, B. J., Anderson, R. E. and Tatham, R. L. (2006). Multivariate Data Analysis. (6 ${ }^{\text {th }}$ ed.). Upper Saddle River, NJ. Prentice-Hall.

Hennart, J. F., Kim, D. J., \& Zeng, M. 1998. The impact of joint venture status on the longevity of Japanese stakes in U.S. manufacturing affiliates. Organization Science, 9, pp. 382-395.

Hull, J. c. (2010). Risk Management and Financial Institutions. ( $2^{\text {nd }}$ ed.). Upper Saddle River, NJ. Prentice Hall.

Jara-Bertin, M., Moya, J. A. and Perales, A. R. (2014). Determinants of bank performance: evidence for Latin America. Academia Revista Latinoamericana de Administración, 27(2), pp. 164-182. 
Koutsoyiannis, A. (2001). Theory of Econometrics. ( $2^{\text {nd }}$ ed.). New York. Palgrave.

Li, L., Li, D. and Shi, w. (2011). Internationalization, internalization and the performance of US biopharmaceutical SMEs. The Multinational Business Review, 19(1), pp. 65-93.

Madura, J. (2008). International Corporate Finance. ( $9^{\text {th }}$ ed.). Thomson South-Western.

Matysiak, L. and Bausch, A. (2012). Antecedents of MNE performance: blinded by the obvious in 35 years of literature. Multinational Business Review, 20 (2), pp. 178 - 211.

Morgan, R. E., Strong, C. A. and McGuinness, T. (2003). Product-market positioning and prospector strategy: An analysis of strategic patterns from the resource-based perspective. European Journal of Marketing, 37 (10), pp. 1409 - 1439.

Mogale, L. and Sutherland, M. (2010). Managing virtual teams in multinational companies. South African Journal of Labour Relations, 34 (2), pp. 7-24.

Nguyen, Q. T. K. (2011). The Empirical Literature on Multinational Enterprises, Subsidiaries and Performance. The Multinational Business Review, 19 (1), pp. 47-64.

Northouse, P. (2007). Leadership Theory and Practice. (4 ${ }^{\text {th }}$ ed.). California: Thousand Oaks.

Prentice, w. (1961). Understanding Leadership. Harvard Business Review, pp. 102-109.

Shamir, B. (1995). Social Distance and Charisma: Theoretical Notes and Exploratory Study. Leadership Quarterly, 6, pp. 19-47.

singh, D. (2012). Emerging Economies and Multinational Corporations: An institutional approach to subsidiary management. International Journal of Emerging Markets, 7 (4), pp. 397-410.

Sturm, J. E. and williams, B. (2009). Foreign bank efficiency in Australia: what makes a difference? Managerial Finance, 35 (2), pp. 180-201.

Sufian, F. (2012). Determinants of Multinational Banks' Subsidiary Performance: the host and home country effects. Journal of Economic and Administrative Sciences, 28 (2), pp. $130-155$.

Tetteh, M. L. (2014). Local versus foreign bank performance: the case of Ghana. Banks and Bank Systems, 9 (3), pp. 43-49.

Trujillo-Ponce, A. (2013). What determines the profitability of banks? Evidence from Spain. Accounting and Finance, 53, pp. 561-586.

Venaik, S., Midgley, D. F. and Devinney, T. M. (2005). Dual paths to performance: the impact of global pressures on MNC subsidiary conduct and performance. Journal of International Business Studies, 36, pp. 655-675. 
Venzin, M., Kumar, V. and Kleine, J. (2008). Internationalization of Retail Banks: A Micro-Level Study of the Multinationality-Performance Relationship. Management International Review, 48 (4), pp. 463-485.

Yukl, G. (1998). Leadership in Organizations. (4 ${ }^{\text {th }}$ ed.). Englewood Cliffs, NJ.: Prentice- Hall. 